\title{
Effect of Transition Metal Mixing on Reactivities of Magnesium Oxide for Chemical Heat Pump
}

\author{
Junichi RYU, Rui TAKAHASHI, \\ Naoya HIRAO and Yukitaka KATO \\ Research Laboratory for Nuclear Reactors, \\ Tokyo Institute of Technology, 2-12-1-N1-22, O-okayama, \\ Meguro-ku, Tokyol52-8550, Japan
}

Keywords: Chemical Heat Pump, Magnesium Oxide, Mixed Oxide

The mixing effect of transition metal ion into magnesium hydroxide on dehydration and hydration reactivity was studied to develop a new material for chemical heat-storage, because the mixing effect was expected to reduce dehydration-temperature, corresponding to heat-storage temperature, of authentic magnesium hydroxide. Two-components composite materials mixed with some content of nickel ion or cobalt ion into magnesium hydroxide were tested, respectively. It was demonstrated that the dehydration-temperatures of the composites were shifted to lower temperature below $300^{\circ} \mathrm{C}$ with increase of nickel or cobalt content in comparison with dehydration-temperature of authentic magnesium oxide of $350^{\circ} \mathrm{C}$. These composites showed higher hydration reactivity than that for authentic magnesium oxide under the same reaction condition, and were expected to be applicable to heat utilization of middletemperature waste heat less than $300^{\circ} \mathrm{C}$.

\section{Introduction}

The heat-storage technologies of waste heat from industrial processes and co-generation systems will be contribute to "Energy Saving". Especially, the technologies of chemical heat-storage are very interesting in view of their heat-storage capacity. In recent years, some kind of technologies for chemical heat pump and chemical heat-storage are widely studied (Wongsuwan et al., 2001; Hirata et al., 2003; Kumita et al., 2003; Li et al., 2004; Abliz et al., 2004; Vernikovskaya et al., 2007) for the reduction of energy consumption and $\mathrm{CO}_{2}$ emission.

Chemical heat pump system with the reaction between magnesium oxide and water vapor has been reported by our group (Kato et al., 1996).

$$
\begin{array}{r}
\mathrm{MgO}(\mathrm{s})+\mathrm{H}_{2} \mathrm{O}(\mathrm{g}) \rightleftarrows \mathrm{Mg}(\mathrm{OH})_{2}(\mathrm{~s}) \\
\Delta H^{\circ}=-81 \mathrm{~kJ} \mathrm{~mol}^{-1}
\end{array}
$$

In this system, dehydration of magnesium hydroxide as an operation for heat-storage would proceed at about $250^{\circ} \mathrm{C}$ thermodynamically; however, thermal energy above $350^{\circ} \mathrm{C}$ is required for the reaction practically. Thus, some modification of this system is required to

Received on May 21, 2007; accepted on July 10, 2007. Correspondence concerning this article should be addressed to J. Ryu (E-mail address: cyliu@nr.titech.ac.jp).

Presented at International Symposium on Innovative Materials for Processes in Energy Systems, IMPRES, Kyoto, October, 2007. be applicable to heat utilization below $300^{\circ} \mathrm{C}$ at which huge amount of waste heat is emitted. Figure 1 shows the reaction equilibriums between metal oxides $(\mathrm{MgO}$, $\mathrm{NiO}$, and $\mathrm{CoO}$ ) and water vapor.

$$
\begin{array}{r}
\mathrm{CoO}(\mathrm{s})+\mathrm{H}_{2} \mathrm{O}(\mathrm{g}) \rightleftarrows \mathrm{Co}(\mathrm{OH})_{2}(\mathrm{~s}) \\
\Delta H^{\circ}=-60 \mathrm{~kJ} \mathrm{~mol}^{-1} \\
\mathrm{NiO}(\mathrm{s})+\mathrm{H}_{2} \mathrm{O}(\mathrm{g}) \rightleftarrows \mathrm{Ni}(\mathrm{OH})_{2}(\mathrm{~s}) \\
\Delta H^{\circ}=-48 \mathrm{~kJ} \mathrm{~mol}^{-1}
\end{array}
$$

New materials which have intermediate properties of equilibrium between these reactions are expected to be dehydrated below $300^{\circ} \mathrm{C}$.

In this work, hydration and dehydration behaviors of two-components composites of $\mathrm{Mg}_{\alpha} \mathrm{M}_{1-\alpha} \mathrm{O}(\mathrm{M}=\mathrm{Ni}$, Co; $\alpha=0-1)$ as new materials for chemical heat-storage were studied to reduce the reaction-working-temperatures compared with one of authentic $\mathrm{Mg}(\mathrm{OH})_{2}$. The possibility of these composites as material for heatstorage was discussed experimentally by thermogravimetric analysis.

\section{Experimental}

\subsection{Sample preparation}

Composites of magnesium hydroxides contained with other metal ion $(\mathrm{Ni}, \mathrm{Co})$ were prepared by coprecipitation method. $\mathrm{Mg}\left(\mathrm{NO}_{3}\right)_{2} \cdot 6 \mathrm{H}_{2} \mathrm{O}(99 \%$, Wako Pure Chemical Industries, Ltd.), $\mathrm{Ni}\left(\mathrm{NO}_{3}\right)_{2} \cdot 6 \mathrm{H}_{2} \mathrm{O}$ (99.9\%, Wako Pure Chemical Industries, Ltd.), and 


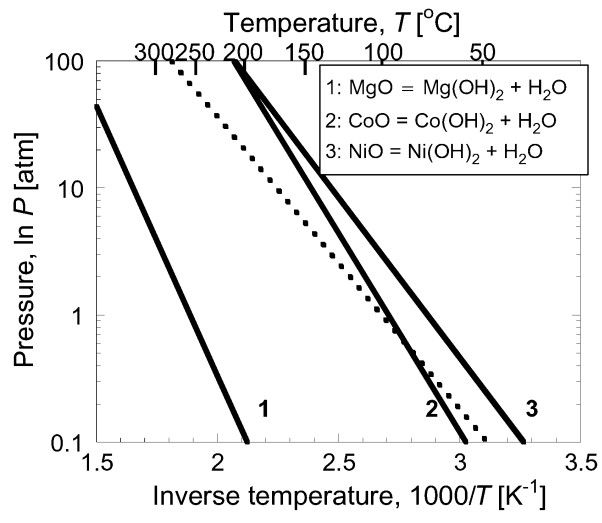

Fig. 1 Reaction equilibriums between metal oxides and water vapor (solid lines) and vapor liquid equilibrium of water (dashed line)

$\mathrm{Co}\left(\mathrm{NO}_{3}\right)_{2} \cdot 6 \mathrm{H}_{2} \mathrm{O}(99.5 \%$, Wako Pure Chemical Industries, Ltd.) were used as precursors for each sample. The precursors were mixed in an aqueous solution with a prescribed molar ratio, and stirred for a few minutes at room temperature. Next, this aqueous solution was added to $1 \mathrm{~N} \mathrm{NaOHaq}$ for precipitate formation, and the slurry was stirred for $1 \mathrm{~h}$ at $60^{\circ} \mathrm{C}$. Finally, the precipitate was collected by filtrating of slurry after washing by de-ionized water, and dried overnight at $120^{\circ} \mathrm{C}$. Additionally, physical mixtures of $\mathrm{Mg}(\mathrm{OH})_{2}-\mathrm{Ni}(\mathrm{OH})_{2}$ and $\mathrm{Mg}(\mathrm{OH})_{2}-\mathrm{Co}(\mathrm{OH})_{2}$ with 1:1 molar ratio as reference samples were prepared from its authentic hydroxides (both 99.9\%, Wako Pure Chemical Industries, Ltd.) by physically mixing using a crucible.

1.2 Reaction test between sample and water vapor

The reactivity between the prepared composite and water vapor was measured by thermo gravimetric (TG) method by using a thermobalance (TGD9600, ULVAC Inc.).

1.2.1 Thermal decomposition of hydroxide The measurement of thermal decomposition for composites as hydroxide was carried out from 130 to $400^{\circ} \mathrm{C}$ with $5^{\circ} \mathrm{C} \mathrm{min}{ }^{-1}$ of temperature ramping rate with 100

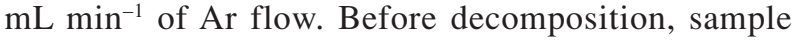
was dried at $130^{\circ} \mathrm{C}$ for $10 \mathrm{~min}$ for removing physically adsorbed water.

1.2.2 Dehydration of sample The sample was charged into a cell of the balance as hydroxide state. The cell was heated up to targeted dehydration-tem-

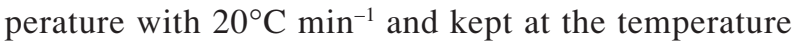
for $30 \mathrm{~min}$ with $100 \mathrm{~mL} \mathrm{~min}^{-1}$ of Ar flow. Before dehydration, sample was dried at $130^{\circ} \mathrm{C}$ for $10 \mathrm{~min}$ for removing physically adsorbed water.

1.2.3 Hydration of sample Dehydrated sample in the balance was cooled down to $110^{\circ} \mathrm{C}$ with $100 \mathrm{~mL}$ $\mathrm{min}^{-1}$ of Ar flow, and water vapor carried with Ar flow was induced in the balance for hydration for $80 \mathrm{~min}$. After hydration operation, vapor supply was stopped and dry Ar gas was supplied at the same hydration-

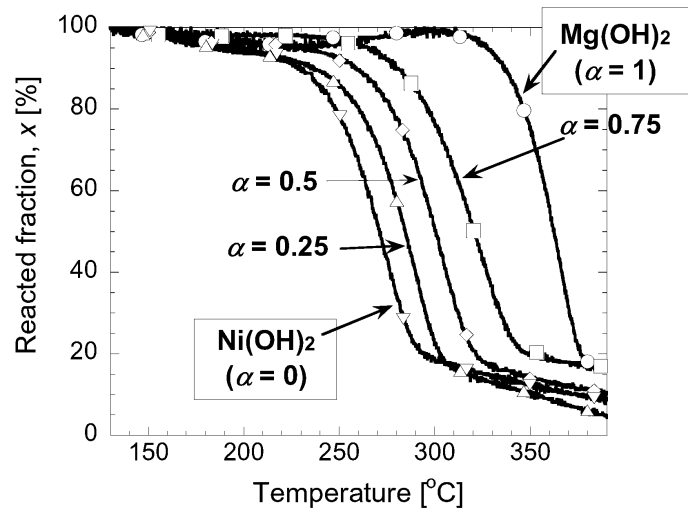

Fig. 2 Thermal decomposition curves of $\mathrm{Mg}_{\alpha} \mathrm{Ni}_{1-\alpha}(\mathrm{OH})_{2}$ composites

temperature to remove physically adsorbed water on the sample for $20 \mathrm{~min}$, and the second dehydration operation was carried out by heating up the sample to the original dehydration-temperature.

\subsection{Reactivity evaluation}

The reacted fraction, $x$ (molar ratio of hydroxide form in sample) is determined as:

$$
x=\left(1+\frac{m_{\mathrm{H}_{2} \mathrm{O}}}{\left(M_{\mathrm{H}_{2} \mathrm{O}} / M_{\text {Hydroxide }}\right) \cdot m_{\text {Hydroxide }}}\right) \times 100
$$

where $M_{\mathrm{H}_{2} \mathrm{O}}$ is molar weight of water, $M_{\text {Hydroxide }}$ is molar weight of hydroxide, $m_{\mathrm{H}_{2} \mathrm{O}}$ is changing of sample weight, and $m_{\text {Hydroxide }}$ is initial sample weight as hydrated form, respectively. The sample weight under dehydration mode is decreased, thus the value of $m_{\mathrm{H}_{2} \mathrm{O}}$ for dehydration mode is negative. On the other hand, the sample weight under hydration mode is increased, thus the value of $m_{\mathrm{H}_{2} \mathrm{O}}$ for hydration mode is positive. Therefore, reacted fraction of sample as hydrated form is $100 \%$, and that as dehydrated form is $0 \%$.

\section{Results and Discussion}

\subsection{Thermal decomposition of composites}

The thermal-decomposition curves of $\mathrm{Mg}_{\alpha} \mathrm{Ni}_{1-\alpha^{-}}$ $(\mathrm{OH})_{2}$ and $\mathrm{Mg}_{\alpha} \mathrm{Co}_{1-\alpha}(\mathrm{OH})_{2}$ composites are shown in Figures 2 and 3. Decomposition, that is, dehydration of $\mathrm{Mg}(\mathrm{OH})_{2}$ was started from about $310^{\circ} \mathrm{C}$, and those of $\mathrm{Mg}_{\alpha} \mathrm{Ni}_{1-\alpha}(\mathrm{OH})_{2}$ were shifted to lower temperature with increase of $\mathrm{Ni}$ content. In case of $\mathrm{Mg}_{\alpha} \mathrm{Co}_{1-\alpha}(\mathrm{OH})_{2}$ mixed hydroxides, the trend of dehydration-temperature did not change monotonously with increase of Co content, and authentic $\mathrm{Co}(\mathrm{OH})_{2}$, showed relatively higher decomposition-temperature than other lower content composites. It suggested that dehydration of authentic $\mathrm{Co}(\mathrm{OH})_{2}$ had unique reaction mechanism such as multi-step dehydration via $\mathrm{Co}_{3} \mathrm{O}_{4}$ (Ramesh et al., 2003). 


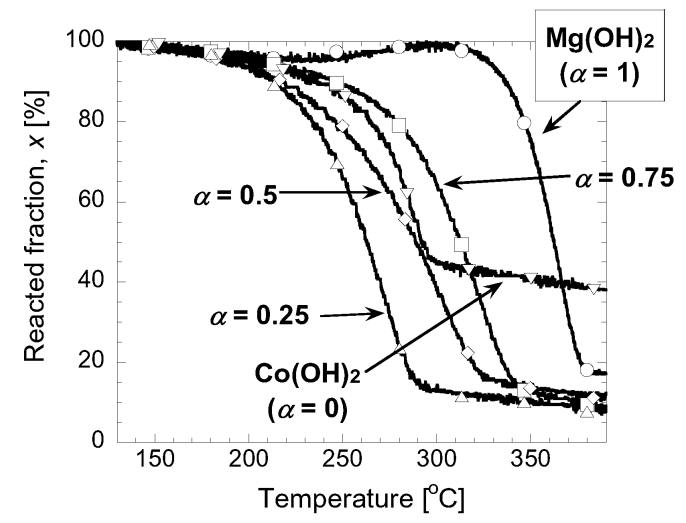

Fig. 3 Thermal decomposition curves of $\mathrm{Mg}_{\alpha} \mathrm{Co}_{1-\alpha}(\mathrm{OH})_{2}$ composites

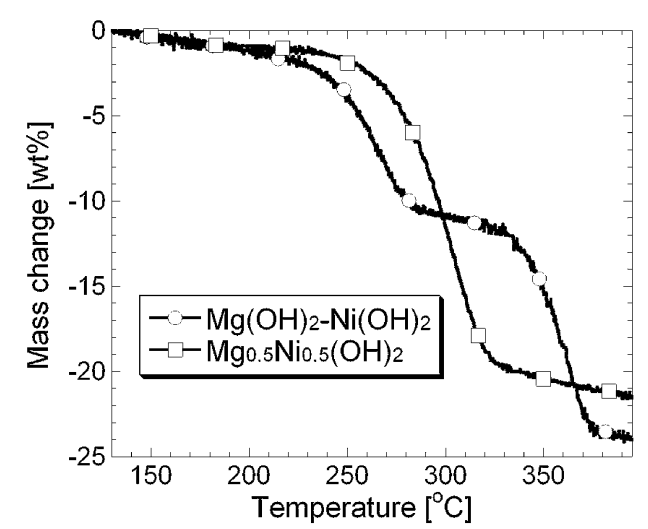

Fig. 4 Thermal decomposition curves of $\mathrm{Mg}_{0.5} \mathrm{Ni}_{0.5}(\mathrm{OH})_{2}$ and $\mathrm{Mg}(\mathrm{OH})_{2}-\mathrm{Ni}(\mathrm{OH})_{2}$ mixture $(1: 1)$

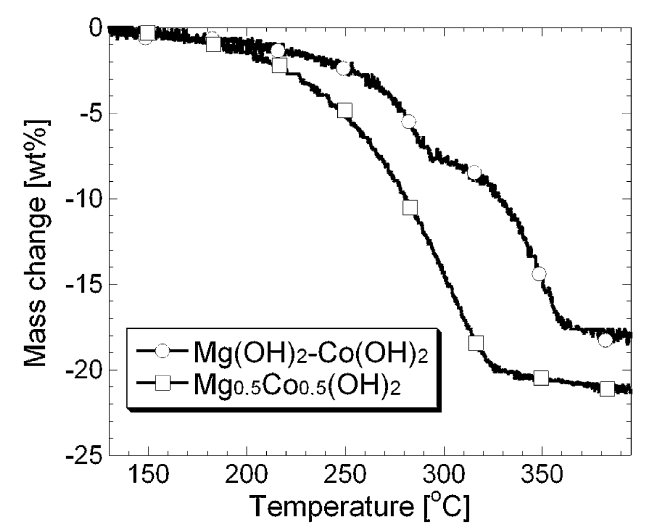

Fig. 5 Thermal decomposition curves of $\mathrm{Mg}_{0.5} \mathrm{Co}_{0.5}(\mathrm{OH})_{2}$ and $\mathrm{Mg}(\mathrm{OH})_{2}-\mathrm{Co}(\mathrm{OH})_{2}$ mixture $(1: 1)$

Figures $\mathbf{4}$ and $\mathbf{5}$ show the thermal-decomposition curves of physical mixtures of $\mathrm{Mg}(\mathrm{OH})_{2}-\mathrm{Ni}(\mathrm{OH})_{2}$ and $\mathrm{Mg}(\mathrm{OH})_{2}-\mathrm{Co}(\mathrm{OH})_{2}$, respectively. The decomposition curves of these mixtures having two-steps dehydration were clearly different from the composites of $\mathrm{Mg}_{0.5} \mathrm{Ni}_{0.5}(\mathrm{OH})_{2}$ and $\mathrm{Mg}_{0.5} \mathrm{Co}_{0.5}(\mathrm{OH})_{2}$ having single-step

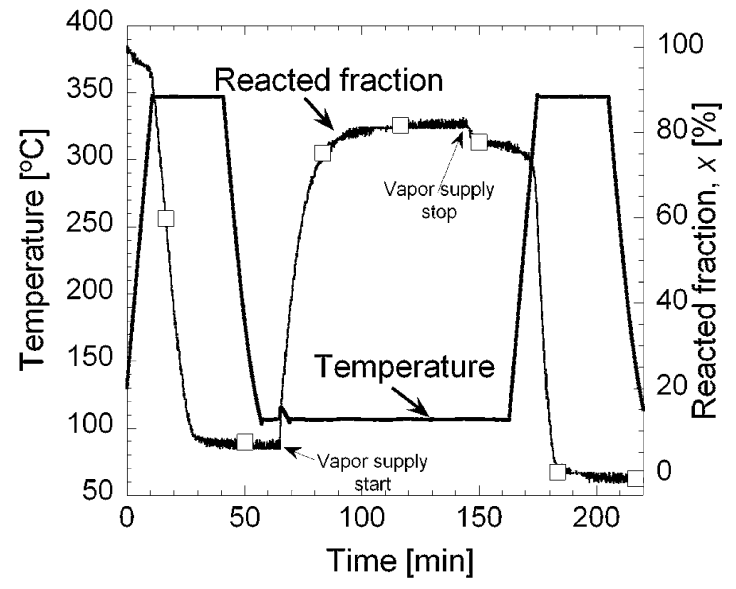

Fig. 6 Dehydration and hydration behavior of $\mathrm{Mg}(\mathrm{OH})_{2}$ $\left(T_{\mathrm{d}}=350^{\circ} \mathrm{C}, T_{\mathrm{h}}=110^{\circ} \mathrm{C}, T_{\mathrm{s}}=85^{\circ} \mathrm{C}\right)$

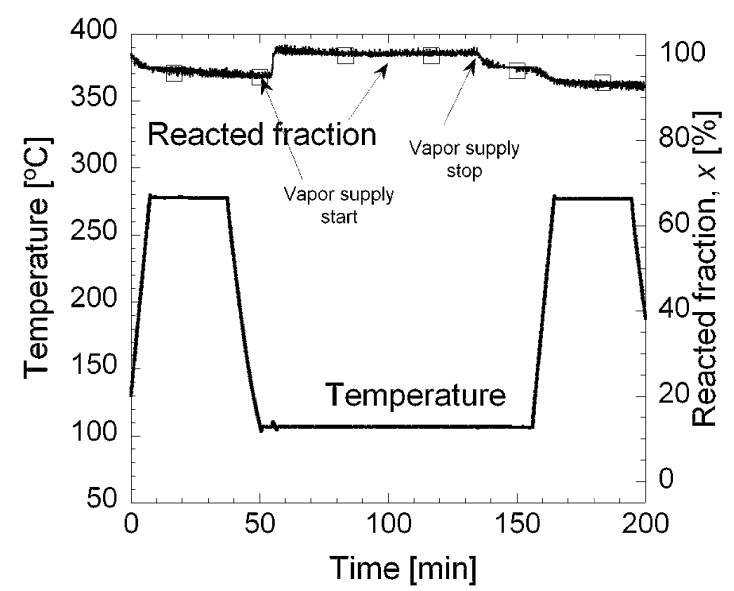

Fig. 7 Dehydration and hydration behavior of $\mathrm{Mg}(\mathrm{OH})_{2}$ $\left(T_{\mathrm{d}}=280^{\circ} \mathrm{C}, T_{\mathrm{h}}=110^{\circ} \mathrm{C}, T_{\mathrm{s}}=85^{\circ} \mathrm{C}\right)$

dehydration. If crystal phases of $\mathrm{Mg}_{0.5} \mathrm{Ni}_{0.5}(\mathrm{OH})_{2}$ and $\mathrm{Mg}_{0.5} \mathrm{Ni}_{0.5}(\mathrm{OH})_{2}$ were separated to each authentic components, dehydration behaviors of these samples should be close to these physical mixtures. Therefore, these results indicate that the composites of $\mathrm{Mg}_{0.5} \mathrm{Ni}_{0.5}(\mathrm{OH})_{2}$ and $\mathrm{Mg}_{0.5} \mathrm{Co}_{0.5}(\mathrm{OH})_{2}$ form new phase such as solid solution.

\subsection{Hydration behavior of composites}

Figure 6 shows the hydration behavior of $\mathrm{Mg}(\mathrm{OH})_{2}$ under the reaction-temperature of $110^{\circ} \mathrm{C}$ and vapor pressure of $57.8 \mathrm{kPa}\left(T_{\mathrm{s}}=85^{\circ} \mathrm{C}\right)$, after dehydration at $350^{\circ} \mathrm{C}$ for $30 \mathrm{~min}$. The reacted fraction reached to $6.4 \%$ after dehydration operation at $350^{\circ} \mathrm{C}$. By the hydration of sample and for $80 \mathrm{~min}$, reacted fraction of this sample reached to $81.0 \%$, and it decreased to $77.1 \%$ after stopping of vapor-supply. Finally, reacted fraction of this sample decreased to almost $0 \%$ by second dehydration at $350^{\circ} \mathrm{C}$. On the other hands, dehydration of $\mathrm{Mg}(\mathrm{OH})_{2}$ at $280^{\circ} \mathrm{C}$ showed small reactivity as shown in Figure 7. Figure 7 indicates that authentic 


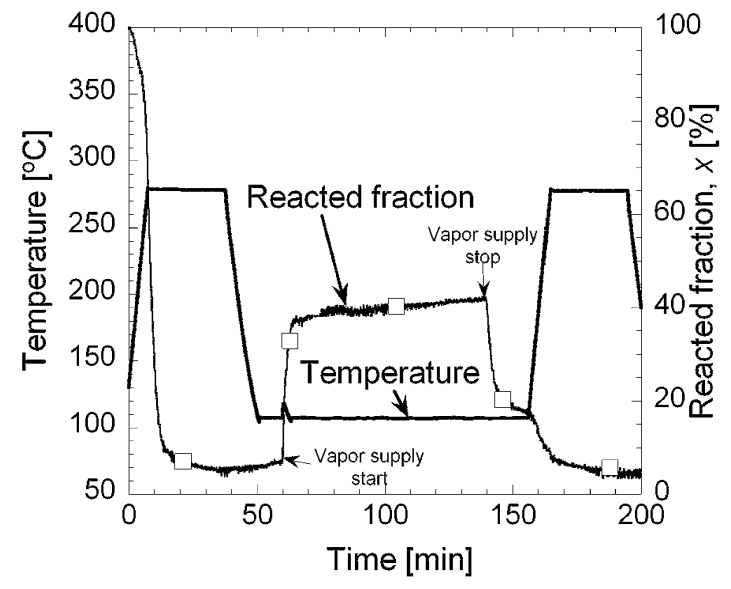

Fig. 8 Dehydration and hydration behavior of $\mathrm{Ni}(\mathrm{OH})_{2}$ $\left(T_{\mathrm{d}}=280^{\circ} \mathrm{C}, T_{\mathrm{h}}=110^{\circ} \mathrm{C}, T_{\mathrm{s}}=85^{\circ} \mathrm{C}\right)$

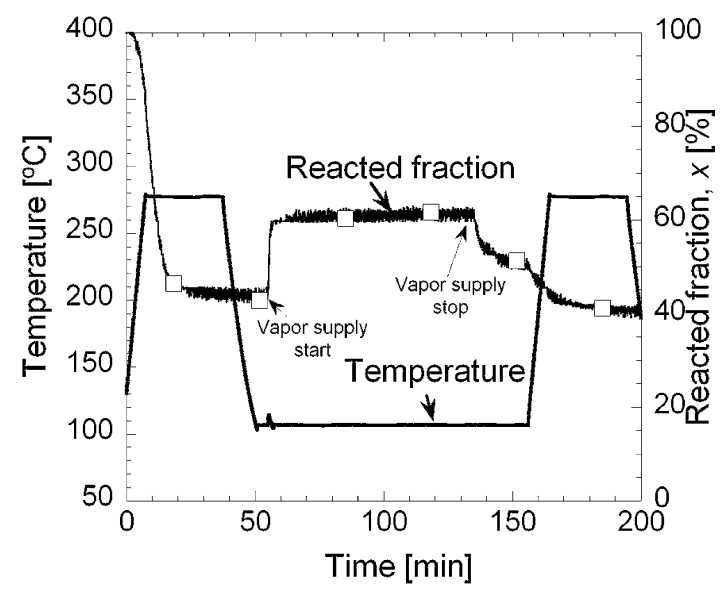

Fig. 9 Dehydration and hydration behavior of $\mathrm{Co}(\mathrm{OH})_{2}$ $\left(T_{\mathrm{d}}=280^{\circ} \mathrm{C}, T_{\mathrm{h}}=110^{\circ} \mathrm{C}, T_{\mathrm{s}}=85^{\circ} \mathrm{C}\right)$

$\mathrm{Mg}(\mathrm{OH})_{2}$ is not suitable for chemical heat-storage at $280^{\circ} \mathrm{C}$.

Figures 8 and 9 show the hydration behavior of $\mathrm{Ni}(\mathrm{OH})_{2}$ and $\mathrm{Co}(\mathrm{OH})_{2}$ under the same reaction condition for $\mathrm{Mg}(\mathrm{OH})_{2}$ shown in Figure 7, respectively. In case of $\mathrm{Ni}(\mathrm{OH})_{2}$, the reacted fraction reached to $6.6 \%$ by dehydration operation at $280^{\circ} \mathrm{C}$. By the hydration of sample, reacted fraction reached to $41.0 \%$, and it decreased to $18.2 \%$ after stopping of vapor supply. Finally, reacted fraction of this sample decreased to about $5 \%$ by dehydration at $280^{\circ} \mathrm{C}$. In case of $\mathrm{Co}(\mathrm{OH})_{2}$, reacted fractions at the conditions of after first dehydration, hydration, before second dehydration, and after second dehydration were $45.5,61.5,50.7$, and $42 \%$, respectively. The difference between reacted fraction at the point of vapor-supply-stop and that of temperature-ramping-start for the second dehydration is corresponding to amount of physically adsorbed water on sample. According to the changing of reacted fraction in the hydration period, contribution of water vapor

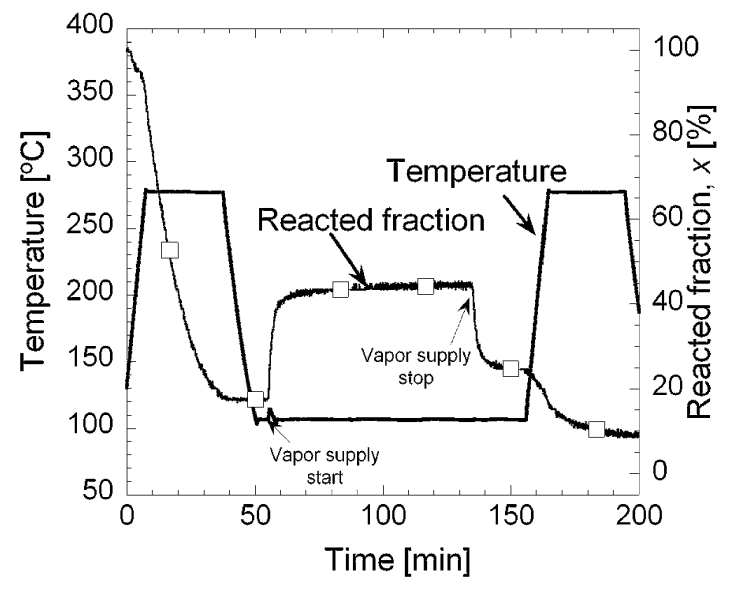

Fig. 10 Dehydration and hydration behavior of $\mathrm{Mg}_{0.5} \mathrm{Ni}_{0.5}(\mathrm{OH})_{2}\left(T_{\mathrm{d}}=280^{\circ} \mathrm{C}, T_{\mathrm{h}}=110^{\circ} \mathrm{C}, T_{\mathrm{s}}=85^{\circ} \mathrm{C}\right)$

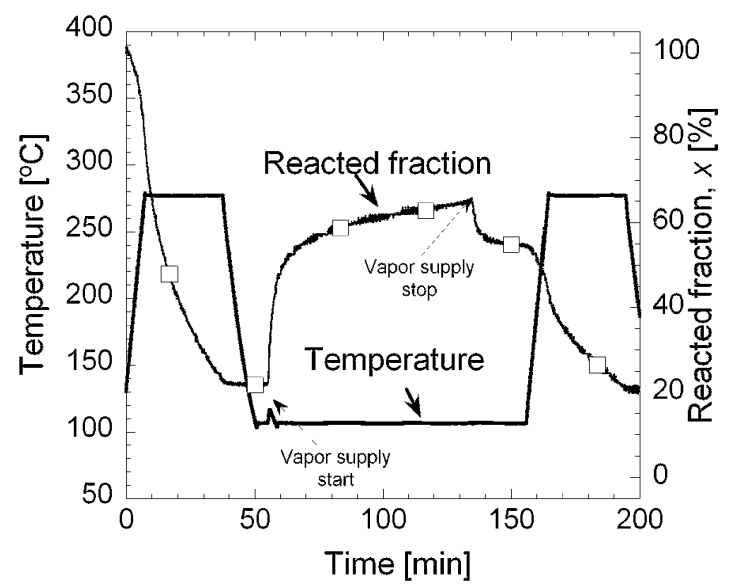

Fig. 11 Dehydration and hydration behavior of $\mathrm{Mg}_{0.5} \mathrm{Co}_{0.5}(\mathrm{OH})_{2}\left(T_{\mathrm{d}}=280^{\circ} \mathrm{C}, T_{\mathrm{h}}=110^{\circ} \mathrm{C}, T_{\mathrm{s}}=85^{\circ} \mathrm{C}\right)$

adsorption on these samples was higher than chemical reaction with hydroxide formation for both samples. Therefore, the performances of these samples are not enough as materials for chemical heat-storage.

Figures $\mathbf{1 0}$ and $\mathbf{1 1}$ show the hydration behavior of composite materials of $\mathrm{Mg}_{0.5} \mathrm{Ni}_{0.5}(\mathrm{OH})_{2}$ and $\mathrm{Mg}_{0.5} \mathrm{Co}_{0.5}(\mathrm{OH})_{2}$ under the same reaction condition for $\mathrm{Mg}(\mathrm{OH})_{2}$ shown in Figure 7, respectively. In case of $\mathrm{Mg}_{0.5} \mathrm{Ni}_{0.5}(\mathrm{OH})_{2}$, reacted fractions at the conditions of after first dehydration, hydration, before second dehydration, and after second dehydration were 17.6, 44.0, 24.9 , and $10 \%$, respectively. The shape of hydration behavior for this sample is similar to one of authentic $\mathrm{Ni}(\mathrm{OH})_{2}$ depicted in Figure 8, thus the performance of this sample is also not enough as material for chemical heat-storage in this condition. In case of $\mathrm{Mg}_{0.5} \mathrm{Co}_{0.5}(\mathrm{OH})_{2}$, reacted fractions at the conditions of after first dehydration, hydration, before second dehydration, and after second dehydration were 22.1, 64.5, 54.9 , and $20 \%$, respectively. Contribution of hydroxide 


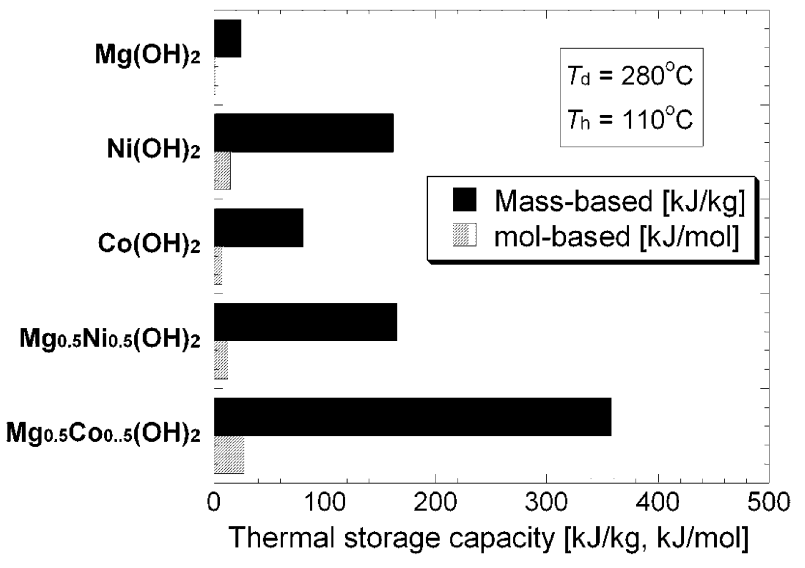

Fig. 12 Thermal storage capacity of $\mathrm{Mg}(\mathrm{OH})_{2}, \mathrm{Ni}(\mathrm{OH})_{2}$, $\mathrm{Co}(\mathrm{OH})_{2}$, and its mixed hydroxides $\left(T_{\mathrm{d}}=280^{\circ} \mathrm{C}, T_{\mathrm{h}}\right.$ $=110^{\circ} \mathrm{C}, T_{\mathrm{s}}=85^{\circ} \mathrm{C}$ )

formation was dominant compared with one of water vapor adsorption on the sample in hydration. Therefore, this composite is expected to have potential as a new material for chemical heat-storage having dehydration-temperature of about $280^{\circ} \mathrm{C}$.

\subsection{Thermal-storage performance of composites}

Thermal-storage performances of the composite samples investigated in the last section as materials for heat-storage were estimated using the results of the experimental hydration-measurement. The performances were calculated from the reaction heat and measured conversion of hydroxide formation, adsorption heat of water vapor on sample, and amount of adsorbed water. Here, the reaction heats of authentic hydroxide $\left(\mathrm{Mg}(\mathrm{OH})_{2}, \mathrm{Ni}(\mathrm{OH})_{2}\right.$, and $\left.\mathrm{Co}(\mathrm{OH})_{2}\right)$ have been reported, but that of mixed hydroxides $\left(\mathrm{Mg}_{0.5} \mathrm{Ni}_{0.5}(\mathrm{OH})_{2}\right.$ and $\mathrm{Mg}_{0.5} \mathrm{Co}_{0.5}(\mathrm{OH})_{2}$ ) have not been reported; therefore, reaction heat of composites were assumed to be linearly related to the ratio of authentic oxide. Also, it was assumed that adsorption heat of water vapor on sample was equal to the condensation heat of water. The conversion of hydroxide formation and amount of adsorbed water were derived from the results of TG measurement.

Figure 12 shows the estimated thermal-storage capacities of the samples studied in this work. The capacity of $\mathrm{Mg}(\mathrm{OH})_{2}$ was small $\left(25 \mathrm{~kJ} \mathrm{~kg}^{-1}\right)$ under the dehydration operation at $280^{\circ} \mathrm{C}$. On the other hand, the capacities of composites in hydroxide were higher than that of $\mathrm{Mg}(\mathrm{OH})_{2}$. Especially, that of $\mathrm{Mg}_{0.5} \mathrm{Co}_{0.5}(\mathrm{OH})_{2}$ was estimated at $358 \mathrm{~kJ} \mathrm{~kg}^{-1}$. These results mean that composite mixing of nickel or cobalt ions is effective for the reactivity enhancement of $\mathrm{Mg}(\mathrm{OH})_{2}$ at lower than $300^{\circ} \mathrm{C}$.

\section{Conclusions}

Two-components composites, $\mathrm{Mg}_{\alpha} \mathrm{Ni}_{1-\alpha}(\mathrm{OH})_{2}$ and $\mathrm{Mg}_{\alpha} \mathrm{Co}_{1-\alpha}(\mathrm{OH})_{2}$, prepared by co-precipitation method, were evaluated as new materials for chemical heat-storage in this study. $\mathrm{Mg}_{\alpha} \mathrm{Ni}_{1-\alpha}(\mathrm{OH})_{2}$ and $\mathrm{Mg}_{\alpha} \mathrm{Co}_{1-\alpha}(\mathrm{OH})_{2}$ showed monotonous thermal-decomposition curves, although physical mixtures of these authentic hydroxides showed two-steps curves. The dehydration-temperatures of these composites in hydrated state were shifted to lower temperature with increase of nickel or cobalt content, and showed higher hydration reactivity in comparison with authentic $\mathrm{Mg}(\mathrm{OH})_{2}$. Especially, $\mathrm{Mg}_{0.5} \mathrm{Co}_{0.5}(\mathrm{OH})_{2}$ was expected to be a candidate of new materials for chemical heat-storage lower than $300^{\circ} \mathrm{C}$ at which authentic $\operatorname{Mg}(\mathrm{OH})_{2}$ can not be applicable to material for chemical heat-storage. The thermal-storage capacity of $\mathrm{Mg}_{0.5} \mathrm{Co}_{0.5}(\mathrm{OH})_{2}$ was estimated at 358 $\mathrm{kJ} \mathrm{kg}^{-1}$, under the reaction-temperature at $110^{\circ} \mathrm{C}$ and vapor pressure of $57.8 \mathrm{kPa}$, after dehydration at $280^{\circ} \mathrm{C}$. The capacity was 14.3 times as high as one of authentic $\mathrm{Mg}(\mathrm{OH})_{2}$ under the same reaction condition. The composite of magnesium oxide with transition metal oxide studied in this work were expected to be suitable for chemical heat-storage operation less than $300^{\circ} \mathrm{C}$.

\section{Acknowledgements}

This work was partially supported by Grants-of-Aid for Scientific Research (\#18760664) from the Ministry of Education, Science, Sports, and Culture of Japan.

Nomenclat
$M_{\mathrm{H}_{2} \mathrm{O}}$
$M_{\mathrm{Hydroxide}}$
$m_{\mathrm{H}_{2} \mathrm{O}}$
$m_{\mathrm{Hydroxide}}$
$T_{\mathrm{d}}$
$T_{\mathrm{h}}$
$T_{\mathrm{s}}$
$X$

$\alpha$

$\left[\mathrm{g} \mathrm{mol}{ }^{-1}\right]$ $\left[\mathrm{g} \mathrm{mol}^{-1}\right]$ $[\mathrm{mg}]$ $[\mathrm{mg}]$ $\left[{ }^{\circ} \mathrm{C}\right]$ $\left[{ }^{\circ} \mathrm{C}\right]$ $\left[{ }^{\circ} \mathrm{C}\right]$ reacted fraction

$=$ molar fraction of magnesium ion to whole metal

ion in mixed hydroxide

\section{Literature Cited}

Abliz, S., O. Fujioka, H. Ogura and H. Kage; "Reaction Activity of $\mathrm{CaO}$ Particles Prepared by Calcination of Some $\mathrm{CaCO}_{3}$ Materials," J. Chem. Eng. Japan, 37, 815-821 (2004)

Hirata, Y., K. Fujioka and S. Fujiki; "Preparation of Fine Particles of Calcium Chloride with Expanded Graphite for Enhancement of the Driving Reaction for Chemical Heat Pumps," J. Chem. Eng. Japan, 36, 827-832 (2003)

Kato, Y., N. Yamashita, K. Kobayashi and Y. Yoshizawa; "Kinetic Study of the Hydration of Magnesium Oxide for a Chemical Heat Pump," Appl. Therm. Eng., 16, 853-862 (1996)

Kumita, M., S. Mori, T. Yokogoshiya and S. Otsubo; "Adsorption Equilibria for Activated Carbon Fiber/Alcohol Pairs and Their Applicability to Adsorption Refrigerator," J. Chem. Eng. Japan, 36, 812-818 (2003)

Li, J., F. Watanabe, M. Kubota, N. Kobayashi and M. Hasatani; "Heat and Mass Transfer Characteristics of an Active Carbon/ 
Ammonia Adsorption Heat Pump with a Packed Bed Type Absorber," J. Chem. Eng. Japan, 37, 383-390 (2004)

Ramesh, T. N., M. Rajamathi and P. V. Kamath; "Ammonia Induced Precipitation of Cobalt Hydroxide: Observation of Turbostratic Disorder," Solid State Sci., 5, 751-756 (2003)

Vernikovskaya, N. M., N. A. Chumakova, N. M. Bukhavtsova, N. V. Vernikovskaya and Y. I. Aristov; "Modeling of the Limiting
Step of Water Sorption by Composite Sorbents of the Calcium Chloride in Porous Matrix Type," Theor. Found. Chem. Eng., 41, 83-90 (2007)

Wongsuwan, W., S. Kumar, P. Neveu and F. Meunier; "A Review of Chemical Heat Pump Technology and Applications," Appl. Therm. Eng., 21, 1489-1519 (2001) 